\title{
Analisis Bahan Ajar Buku Siswa Bahasa Arab untuk Kelas 6 Madrasah Ibtidaiyah (Pendekatan Saintifik 2013)
}

\author{
Nursobah Fitriani \\ Institut Agama Islam Negeri (IAIN) Syekh Nurjati Cirebon \\ sobah.fn@gmail.com \\ Hasan Saefuloh \\ Institut Agama Islam Negeri (IAIN) Syekh Nurjati Cirebon \\ hasanzf@gmail.com
}

\section{ملخص}

المواد التعليمية في هذه الحالة دور مهم في الوصول إلى بحاح التعلم. فإذا استخدم المواد التعليمية مناسبا بغرض التعلم فعملية التعلم بالطبع فعّال ولكن الظاهرة في مضمار أشار إلى أن المواد التعليمية كانت تستخدم كالمصدر الوحيد للمعلم، فبذالك يكون تركيز المعلم هو كيف يقضي المواد الواردة في المواد التعليمية بدون نظر على المنهج و الكفاءة المحورية (KI) والكفاءة الأساسية (KD). تم طرح السؤال "هل كانت المواد المستخدمة لهذا التعليم قد و في بمعايير المواد التعليمية الجيدة؟" . هذا التحليل يستخدم الأداوات من هيئة المعايير الوطنية للتعليم (BSNP) و نظرية ماكي (Mackey). وهذا البحث يستخدم الطريقة الكيفية. الطريقة الكيفية هي الطريقة لنيل البيانات الدقيقة من البيانات الصحيحة وفيها نتيجة من البيانات الموجودة. وأمّا من نوع البحث الذي يستخدم البحث المكتبي. البحث المكتبي هو بعض نشاطات البحث التى ترتبط بعملية القراءة والتسجيل.

Abstrak

Dewasa ini bahan ajar mempunyai peran yang penting dalam mencapai keberhasilan belajar. Maka pembelajaran akan berjalan dengan efektif jika bahan ajar yang digunakan sesuai dengan tujuan pembelajaran. Namun fenomena dilapangan berbicara bahwa bahan ajar digunakan menjadi satusatunya sumber ajar yang dijadikan pegangan oleh guru, sehingga fokus guru 
adalah bagaimana menghabiskan materi yang terdapat dalam bahan ajar tersebut tanpa melihat kepada kurikulum, Kompetensi Inti (KI), dan Kompetensi Dasar (KD). Pertanyaannya kemudian adalah apakah bahan ajar yang selama ini digunakan sudah memenuhi kriteria bahan ajar yang baik? Analisis ini menggunakan insrumen dari Badan Standar Nasional Pendidikan (BSNP) dan teori Mackey. Dalam penelitian ini, menggunakan metode kualitatif. Metode kualitatif yaitu metode untuk mendapatkan informasiinformasi yang akurat dari informasi-informasi yang benar dan mengambil kesimpulan dari informasi-informasi yang ada. Adapun jenis penelitian yang digunakan adalah penelitian kepustakaan. Penelitian kepustakaan adalah beberapa kegiatan penelitian yang menghubungkan dengan kegiatan membaca dan pencatatan.

\section{Kata Kunci: Bahan Ajar, BSNP, Teori Mackey}

\section{Pendahuluan}

Sumber belajar mencakup apa saja yang digunakan untuk membantu tiap orang dalam belajar dan menampilkan kompetensinya. Sumber belajar meliputi, pesan, orang, bahan, alat, teknik, latar, software, hardware, maupun lingkungan baik yang tersendiri maupun terkombinasi dapat memungkinkan terjadinya proses interaksi belajar mengajar dan meningkatkan kinerja belajar. ${ }^{1}$ Fungsi sumber belajar yaitu meningkatkan produktifitas pelajaran, membantu para guru untuk menggunakan waktu dengan baik, belajar secara mandiri, memberikan dasar keilmuan pada pelajaran, mencontohkan pelajaran secara menyeluruh terutama dengan keberadaan media-media informasi massa. $^{2}$

Dalam hal ini bahan ajar mempunyai peran yang penting dalam mencapai keberhasilan belajar. Maka pembelajaran akan berjalan dengan efektif jika bahan ajar yang digunakan sesuai dengan tujuan pembelajaran. ${ }^{3}$ Namun fenomena dilapangan berbicara bahwa bahan ajar digunakan menjadi satu-satunya sumber ajar yang dijadikan pegangan oleh guru, sehingga fokus guru adalah bagaimana menghabiskan materi

1 Sulistyowati, "Pengembangan Pusat Sumber Belajar dalam Upaya Meningkatkan Mutu Pendidikan" dalam STATEMENT 2 No 3/Oktober 2012, h. 45.

${ }^{2}$ Lely Halimah, "Pemberdayaan Lingkungan Sebagai Sumber Belajar dalam Uapaya Meningkatkan Kompetensi Berbahasa Indonesia Siswa Kelas 4 SD Laboratorium UPI Kampus Cibiru" dalam Pendidikan Dasar No. 10/Oktober 2008, h. 31

${ }^{3}$ Mutiatul Azizah, Pdf Skripsi Analisis Bahan Ajar, digilib.uinsby.ac.id 
yang terdapat dalam bahan ajar tersebut tanpa melihat kepada kurikulum, Kompetensi Inti (KI), dan Kompetensi Dasar (KD). Dilihat dari fenomena ini, betapa sentralnya bahan ajar bagi para guru. Pertanyaannya kemudian adalah "apakah bahan ajar yang selama ini digunakan sudah memenuhi kriteria bahan ajar yang baik?" Sebagaimana telah diketahui, bahwa bahan ajar "buku siswa bahasa Arab" untuk kelas 6 Madrasah Ibtidaiyah (pendekatan saintifik 2013) terbitan Kementerian Agama Republik Indonesia baru digunakan beberapa bulan.

\section{Kesesuaian Bahan Ajar dengan Kompetensi Inti (KI) dan Kompetensi Dasar (KD)}

Saat ini pendidikan di Indonesia menggunakan kurikulum 2013. Pada kurikulum 2013, siswa tidak lagi menjadi objek dari belajar, tapi justru menjadi subyek dengan ikut mengembangkan tema dan materi yang ada. ${ }^{4}$ Dalam kurikulum 2013, standar Isi Kurikulum bahasa Arab 2013 dijabarkan dalam bentuk Kompetensi Inti (KI) dan Kompetensi Dasar (KD) serta Tujuan pembelajaran yang terdiri dari empat kompetensi utama yaitu : Kompetensi Inti Satu (KI-1), Kompetensi Inti Dua (KI-2), Kompetensi Inti Tiga (KI-3), dan Kompetensi Inti Empat (KI4). Keempat kelompok itu menjadi acuan dari kompetensi dasar dan akan menjabarkan dalam setiap peristiwa pembelajaran secara integratif. Kompetensi yang berkenaan dengan sikap kegamaan dan sosial dikembangkan secara tidak langsung (indirect teaching) yaitu pada waktu peserta didik belajar tentang pengetahuan (kompetensi inti 3) dan penerapan pengetahuan (kompetensi inti 4 ). ${ }^{5}$ Selanjutnya penggunaan bahan ajar dapat disesuaikan oleh para guru dengan standar Isi kurikulum di atas.

Kurikulum 2013 (Kurtilas) adalah desain pengembangan kurikulum baru yang harus didasarkan pada pengertian bahwa kurikulum adalah suatu pola pendidikan untuk jenjang pendidikan tertentu. Desain ini menempatkan mata pelajaran sebagai organisasi

${ }^{4}$ Nur Fitria Nirmala Ratna, Persepsi Guru Kelas II (Dua) terhadap Pelaksanaan Proses Penilaan dalam Kurikulum 2013 di SD Al-Firdaus (Surakarta: Universitas Muhammadiyah Surakarta, 2015). Hal. 1.

5 Mulyani Muds taruna, “Kesiapan Madrasah dalam Pelaksanaan Kurikulum 2013" dalam At-Taqaddum 6 No 2/Nopember 2014, Hal. 215.

El-Ibtikar Vol 7 No 2 Nopember 2018, 115-136 
konten kurikulum yang terbuka dan saling mempengaruhi. Desain kurikulum yang akan digunakan untuk mengembangkan kurikulm baru harus mampu mengaitkan antar konten kurikulum baik yang bersifat horizontal maupun vertikal. ${ }^{6}$

Adapun struktur kurikulum 2013 (Kurtilas) sebagaimana tertuang dalam Lampiran SK DIRJEN Nomor 2676 adalah sebaga berikut: ${ }^{7}$

1. Kompetensi Inti (KI)

Sejalan dengan filosofi progresivisme dalam pendidikan, Kompetensi Inti (KI) ibaratnya adalah anak tangga yang harus ditapaki peserta didik untuk sampai pada kompetensi lulusan jenjang Madrasah Ibtidaiyah sampai pada jenjang Madrasah Aliyah. Kompetensi Inti (KI) meningkat seiring dengan meningkatnya usia peserta didik yang dinyatakan dengan meningkatnya kelas. Sebagai anak tangga menuju ke kompetensi lulusan multidimensi, kompetensi inti (KI) juga memiliki multidimensi. Untuk kemudahan operasionalnya, kompetensi lulusan pada ranah sikap dipecah menjadi dua. Pertama, sikap spiritual yang terkait dengan tujuan pendidikan nasional membentuk peserta didik yang beriman dan bertakwa. Kedua, sikap social yang terkait dengan tujuan pendidikan nasional membentuk peserta didik yang berakhlak mulia, mandiri, demokratis, dan bertanggungjawab. Berikut adalah format Kompetensi Inti (KI) :

a) Kompetensi Inti (KI) untuk aspek spiritual

b) Kompetensi Inti (KI) untuk aspek sosial

c) Kompetensi Inti (KI) untuk aspek pengetahuan

d) Kompetensi Inti (KI) untuk aspek keterampilan

2. Mata Pelajaran

Kompetensi dasar (KD) dibutuhkan untuk mendukung pencapaian kompetensi lulusan melalui Kompetensi Inti (KI). Selain itu, Kompetensi Dasar (KD) diorganisir kedalam berbagai mata pelajaran yang pada gilirannya berfungsi sebagai sumber kompetensi. Mata pelajaran yang dipergunakan sebagai sumber kompetensi tersebut harus mengacu pada ketentuan yang tercantum pada Undang-undang Sistem

6 Lampiran SK DIRJEN Pendidikan Islam, Kurikulum 2013 Mata Pelajaran Pendidikan Agama Islam dan Bahasa Arab di Madrasah Nomor 2676 (2013). Hal. 3.

7 Lampiran SK DIRJEN Pendidikan Islam, Kurikulum 2013 Mata Pelajaran Pendidikan Agama Islam dan Bahasa Arab di Madrasah ..... Hal. 9-39.

El-Ibtikar Vol 7 No 2 Nopember 2018, 115-136 
Pendidikan Nasional Nomor 20 Tahun 2003, khususnya ketentuan pada pasal 37. Selain jenis mata pelajaran yang diperlukan untuk membentuk kompetensi, juga diperlukan beban belajar per minggu dan per semester atau per tahun. Beban belajar ini kemudian didistribusikan ke berbagai mata pelajaran sesuai dengan tuntutan kompetensi yang diharapkan dapat dihasilkan oleh tiap mata pelajaran.

Beban mata pelajaran dan struktur kurikulum Madrasah Ibtidaiyah (MI) adalah sebagai berikut:

\begin{tabular}{|c|c|c|c|c|c|c|c|c|}
\hline \multirow{2}{*}{\multicolumn{3}{|c|}{ Mata Pelajaran }} & \multicolumn{6}{|c|}{$\begin{array}{l}\text { Alokasi Waktu Belajar Per- } \\
\text { Minggu }\end{array}$} \\
\hline & & & I & II & III & IV & $\mathrm{V}$ & VI \\
\hline \multicolumn{9}{|c|}{ Kelompok A } \\
\hline \multirow[t]{5}{*}{1.} & \multicolumn{8}{|c|}{ Pendidikan Agama Islam } \\
\hline & a. & Al-Qur'an hadis & 2 & 2 & 2 & 2 & 2 & 2 \\
\hline & b. & Akidah Akhlak & 2 & 2 & 2 & 2 & 2 & 2 \\
\hline & c. & Fikih & 2 & 2 & 2 & 2 & 2 & 2 \\
\hline & & Sejarah Kebudayaan Islam & - & - & 2 & 2 & 2 & 2 \\
\hline 2. & \multicolumn{2}{|c|}{$\begin{array}{l}\text { Pendidikan Pancasila dan } \\
\text { Kewarganegaraan }\end{array}$} & 5 & 5 & 6 & 5 & 5 & 5 \\
\hline 3. & \multicolumn{2}{|c|}{ Bahasa Indonesia } & 8 & 9 & 10 & 7 & 7 & 7 \\
\hline 4. & \multicolumn{2}{|c|}{ Bahasa Arab } & 2 & 2 & 2 & 2 & 2 & 2 \\
\hline 5. & \multicolumn{2}{|c|}{ Matematika } & 5 & 6 & 6 & 6 & 6 & 6 \\
\hline 6. & \multicolumn{2}{|c|}{ Ilmu Pengetahuan Alam } & - & - & - & 3 & 3 & 3 \\
\hline 7. & \multicolumn{2}{|c|}{ Ilmu Pengetahuan Sosial } & - & - & - & 3 & 3 & 3 \\
\hline \multicolumn{9}{|c|}{ Kelompok B } \\
\hline 1. & \multicolumn{2}{|c|}{ Seni Budaya dan Prakarya } & 4 & 4 & 4 & 5 & 5 & 5 \\
\hline 2. & \multicolumn{2}{|c|}{$\begin{array}{l}\text { Pendidikan Jasmani, Olah Raga, } \\
\text { dan Kesehatan }\end{array}$} & 4 & 4 & 4 & 4 & 4 & 4 \\
\hline \multicolumn{3}{|c|}{ Jumlah Alokasi Waktu Per Minggu } & 34 & 36 & 40 & 43 & 43 & 43 \\
\hline
\end{tabular}

3. Kompetensi Dasar (KD)

Sebagai rangkaian untuk mendukung kompetensi inti (KI), capaian pembelajaran mata pembelajaran diuraikan menjadi kompetensikompetensi dasar (KD). Pencapaian kompetensi inti (KI) adalah melalui pembelajaran kompetensi dasar (KD) yang disampaikan melalui mata pelajaran. Rumusannya dikembangkan dengan memperhatikan karakteristik peserta didik, kemampuan awal, serta ciri dari suatu mata El-Ibtikar Vol 7 No 2 Nopember 2018, 115-136 
pelajaran sebagai pendukung pencapaian. Kompetensi dasar (KD) dbagi menjadi empat kelompok sesuai dengan pengelompokkan kompetensi inti (KI) sebagai berikut :

a) Kelompok 1, kelompok kompetensi dasar (KD) sikap spiritual dalam rangka menjabarkan KI-1

b) Kelompok 2, kelompok kompetensi dasar (KD) sikap sosial dalam rangka menjabarkan $\mathrm{KI}-2$

c) Kelompok 3, kelompok kompetensi dasar (KD) pengetahuan dalam rangka menjabarkan KI-3

d) Kelompok 4, kelompok kompetensi dasar (KD) keterampialn dalam rangka menjabarkan KI-4

Berikut adalah bentuk kompetensi inti (KI) dan kompetensi dasar (KD) untuk pelajaran bahasa Arab Madrasah Ibtidaiyah:

Semester Ganjil (1)

\begin{tabular}{|c|c|}
\hline Kompetensi Inti (KI) & Kompetensi Dasar (KD) \\
\hline $\begin{array}{l}\text { 1. Menerima, menjalankan dan } \\
\text { menghargai ajaran agama } \\
\text { Islam }\end{array}$ & $\begin{array}{l}\text { 1.1 Meresapi makna anugerah } \\
\text { Allah SWT. berupa bahasa } \\
\text { Arab } \\
\text { 1.2 Meresapi makna anugerah } \\
\text { Allah SWT. atas terciptanya } \\
\text { bahasa yang beragam }\end{array}$ \\
\hline $\begin{array}{l}\text { 2. Menunjukkan perilaku } \\
\text { jujur, disiplin, tanggung } \\
\text { jawab, santun, peduli, dan } \\
\text { percaya diri, dalam } \\
\text { berinteraksi dengan } \\
\text { keluarga, teman, guru, dan } \\
\text { tetangganya serta cinta } \\
\text { tanah air }\end{array}$ & 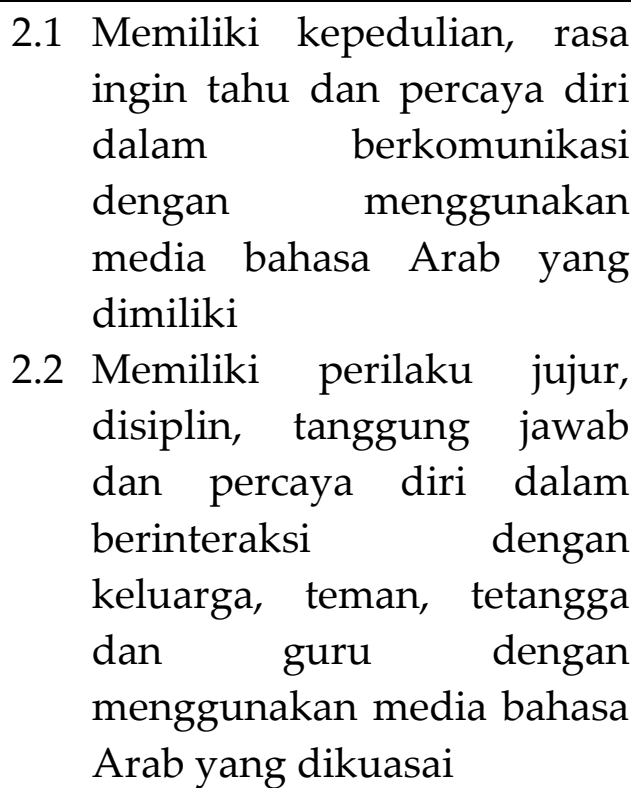 \\
\hline 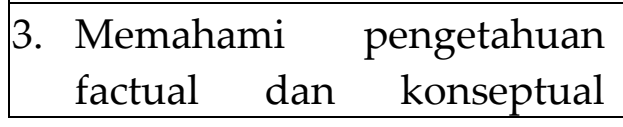 & $\begin{array}{l}\text { 3.1 Mengidentifikasi } \\
\text { huruf, kuta, frasa, dan }\end{array}$ \\
\hline
\end{tabular}




\begin{tabular}{|c|c|}
\hline $\begin{array}{l}\text { dengan menanya dan } \\
\text { mencoba berdasarkan rasa } \\
\text { ingin tahu tentang dirinya, } \\
\text { makhluk ciptaan Tuhan dan } \\
\text { kegiatannya, dan benda- } \\
\text { benda yang dijumpainya } \\
\text { dirumah, sekolah, dan } \\
\text { tempat bermain. }\end{array}$ & 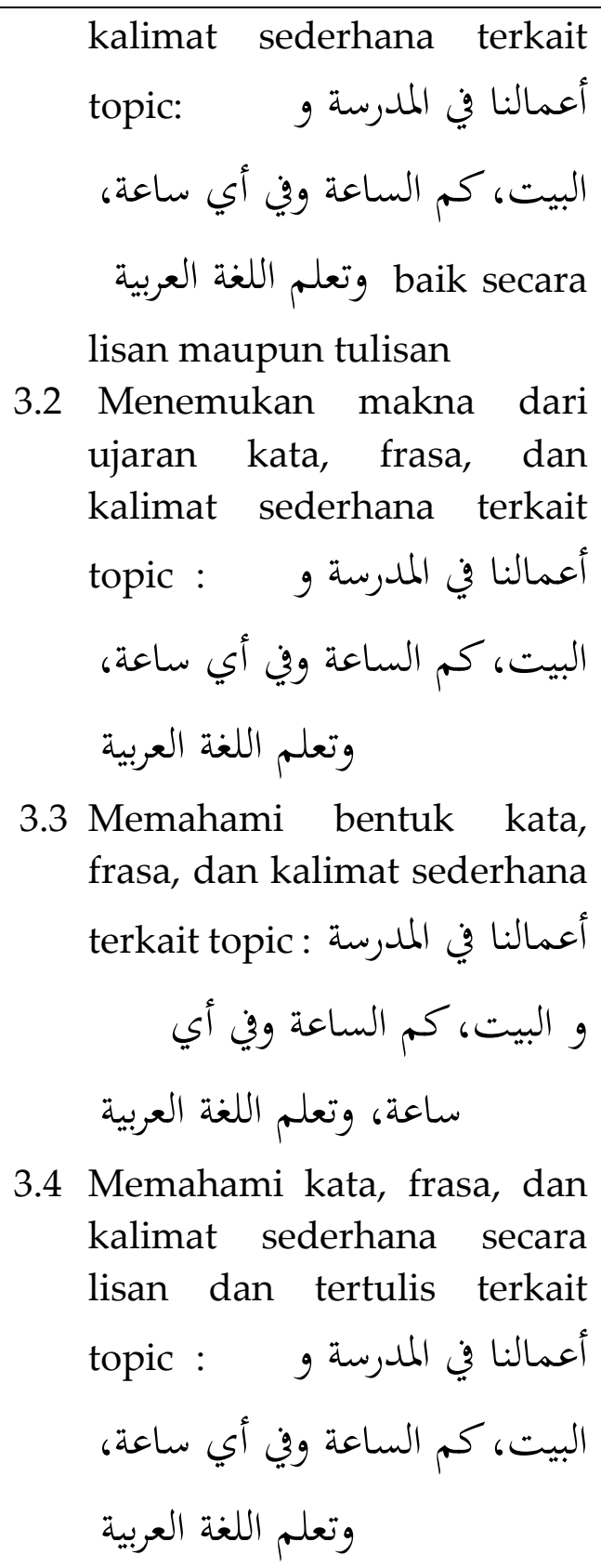 \\
\hline $\begin{array}{l}\text { 4. Menyajikan pengetahuan } \\
\text { factual dan konseptual } \\
\text { dalam bahasa yang jelas, } \\
\text { sistematis, logis, dan kritis, } \\
\text { dalam karya yang estetis, } \\
\text { dalam gerakan yang } \\
\text { mencerminkan anak sehat, }\end{array}$ & $\begin{array}{l}\text { 4.1 Melafalkan bunyi huruf, } \\
\text { kata, frasa, dan kalimat } \\
\text { bahasa Arab terkait topic : } \\
\text { العمالنا في المدرسة و البيت، كمة وفي أي ساعة، وتعلم اللغة }\end{array}$ \\
\hline
\end{tabular}




\begin{tabular}{|c|c|}
\hline $\begin{array}{l}\text { dan dalam tindakan yang } \\
\text { mencerminkan perilaku } \\
\text { anak beriman dan berkahlak } \\
\text { mulia. }\end{array}$ & 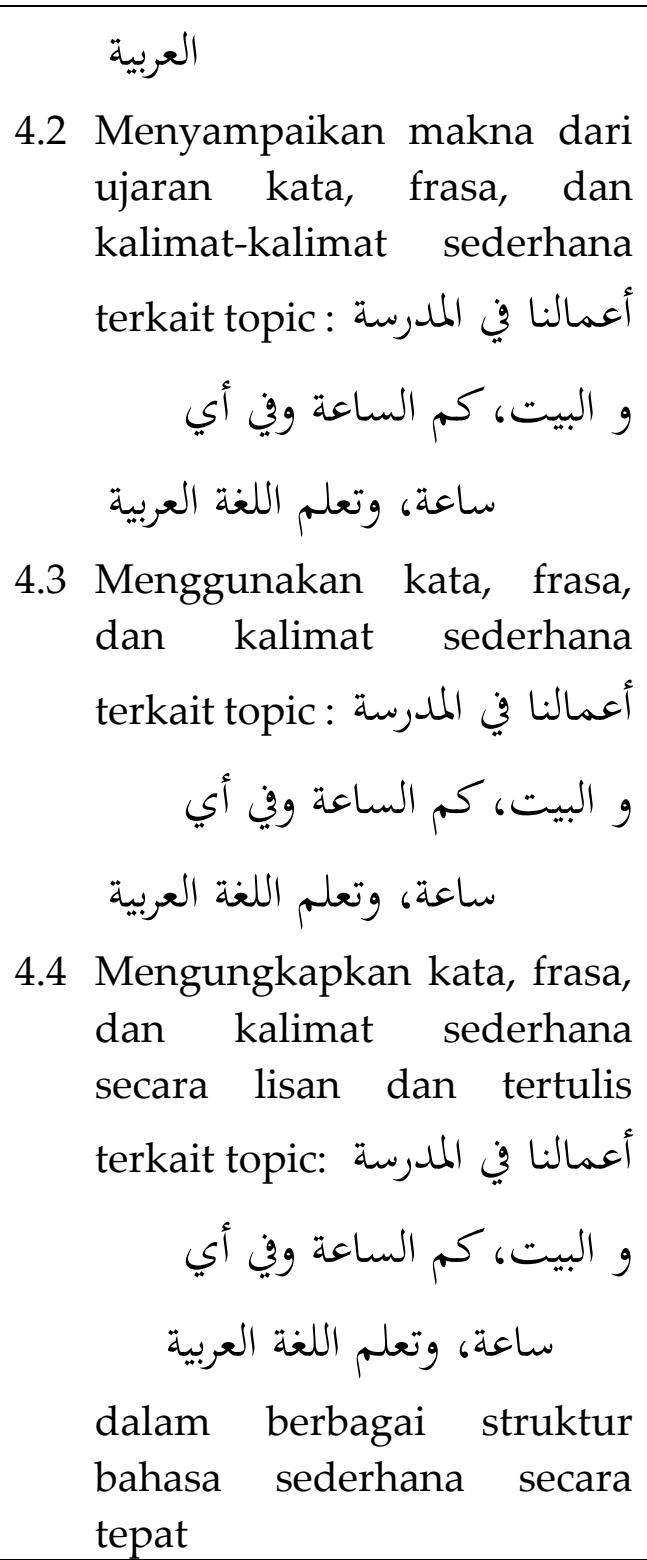 \\
\hline Tarkib: & فعل المضارع، الساعة، فعل الامر \\
\hline
\end{tabular}

Semester Genap (2)

\begin{tabular}{|l|l|}
\hline Kompetensi Inti (KI) & Kompetensi Dasar (KD) \\
\hline $\begin{array}{l}\text { 1. Menerima, menjalankan } \\
\text { dan menghargai ajaran } \\
\text { agama Islam }\end{array}$ & $\begin{array}{r}\text { 1.1 } \text { Meresapi makna anugerah } \\
\text { Allah SWT. berupa bahasa }\end{array}$ \\
& Arab \\
1.2 Meresapi makna anugerah \\
\hline
\end{tabular}




\begin{tabular}{|c|c|}
\hline & $\begin{array}{l}\text { Allah SWT. atas terciptanya } \\
\text { bahasa yang beragam }\end{array}$ \\
\hline $\begin{array}{l}\text { 2. Menunjukkan perilaku } \\
\text { jujur, disiplin, tanggung } \\
\text { jawab, santun, peduli, dan } \\
\text { percaya diri, dalam } \\
\text { berinteraksi dengan } \\
\text { keluarga, teman, guru, dan } \\
\text { tetangganya serta cinta } \\
\text { tanah air }\end{array}$ & 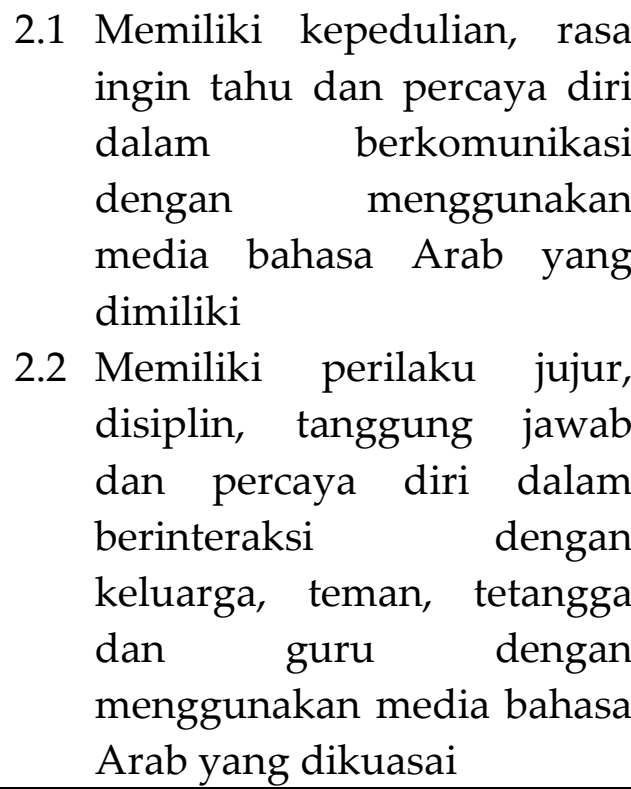 \\
\hline $\begin{array}{l}\text { 3. Memahami pengetahuan } \\
\text { factual dan konseptual } \\
\text { dengan menanya dan } \\
\text { mencoba berdasarkan rasa } \\
\text { ingin tahu tentang dirinya, } \\
\text { makhluk ciptaan Tuhan dan } \\
\text { kegiatannya, dan benda- } \\
\text { benda yang dijumpainya } \\
\text { dirumah, sekolah, dan } \\
\text { tempat bermain. }\end{array}$ & 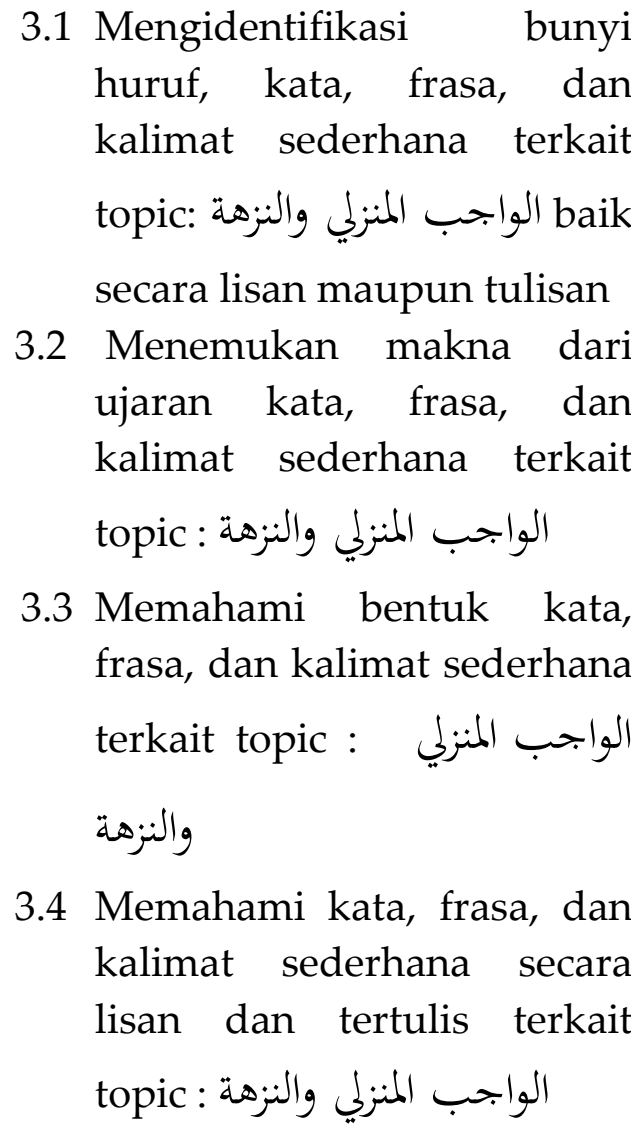 \\
\hline
\end{tabular}


4. Menyajikan pengetahuan dalam bahasa yang jelas, sistematis, logis, dan kritis, dalam karya yang estetis, dalam gerakan yang mencerminkan anak sehat, dan dalam tindakan yang mencerminkan perilaku anak beriman dan berkahlak mulia. factual dan konseptual

4.1 Melafalkan bunyi huruf, kata, frasa, dan kalimat bahasa Arab terkait topic :<smiles>[13CH3][13CH]=C[AlH2]</smiles>

4.2 Menyampaikan makna dari ujaran kata, frasa, dan kalimat-kalimat sederhana terkait topic : الواجب المنزلي والنزهة

4.3 Menggunakan kata, frasa, dan kalimat sederhana terkait topic : الواجب المنزلي والنزهة

4.4 Mengungkapkan kata, frasa, dan kalimat sederhana secara lisan dan tertulis terkait topic: الواجب المنزلي والنزهة dalam berbagai struktur bahasa sederhana secara tepat

Tarkib:

Analisis Kesesuaian Bahan Ajar dengan Kompetensi Inti (KI) Dan Kompetensi Dasar (KD)

Undang-undang Republik Indonesia Nomor 20 Tahun 2003 tentang Sistem Pendidikan Nasional Pasal 35 ayat (3) menyatakan bahwa pengembangan Standar Nasional Pendidikan (SNP) serta pemantauan dan pelaporan pencapaiannya secara nasional dilaksanakan oleh suatu badan standarisasi, penjaminan, dan pengendalian mutu pendidikan. Untuk melaksanakan pasal tersebut, Peraturan Pemerintah Nomor 19 Tahun 2005 (PP No. 19 Tahun 2005) tentang Standar Nasional Pendidikan Pasal 73 ayat (1) mengamanatkan Badan Standar Nasional 
Pendidikan (BSNP) untuk mengembangkan, memantau, dan melaporkan pencapaian SNP secara nasional. ${ }^{8}$

Penilaian bahan ajar "buku siswa bahasa Arab" (pendekatan saintifik 2013) kelas 6 Madrasah Ibtidaiyah dari segi kelayakan isi, terdiri dari 6 subkomponen, dan 18 butir penilaian.

Subkomponen yang pertama, yaitu kesesuaian uraian materi dengan Kompetensi Inti (KI) dan kompetensi dasar (KD) yang terdiri dari 3 butir, yaitu kelengkapan materi, keluasan materi, dan kedalaman materi. Dari segi kelengkapan materi, materi yang disajikan mencakup semua materi yang terkandung dalam kompetensi inti (KI) dan kompetensi dasar (KD). Dari segi keluasan materi, materi-materi mencerminkan jabaran yang mendukung pencapaian semua kompetensi dasar (KD) (mendengar, berbicara, membaca, dan menulis). Dan dari segi kedalaman materi, materi-materinya sudah memuat ketuntasan belajar sesuai kemampuan memahami, menerapkan, dan memperhatikan struktur bahasa.

Subkomponen yang kedua, yaitu keakuratan materi yang terdiri dari 3 butir, yaitu keakuratan gramatika, keakuratan istilah, dan keakuratan gambar dan ilustrasi. Dari segi keakuratan gramatika, gramatika yang disajikan cukup sulit untuk tingkat siswa kelas 6 Madrasah Ibtidaiyah. Dari segi keakuratan istilah, materi-materi sudah menggunakan istilah bahasa Arab yang sesuai dengan pokok bahasan dan pembahasan, tetapi di bab 4 ditemukan ketidaksesuaian dengan pokok bahasan. Dan dari segi kekauratan gambar dan istilah, gambar, foto, dan ilsutrasi yang ditampilkan sudah sesuai dengan tema pokok bahasan dan mudah dipahami pesrta didik, tetapi di bab 5 ditemukan ketidaksesuaian karena antara gambar dan istilah tidak sesuai.

Subkomponen yang ketiga, yaitu kemutakhiran materi yang terdiri dari 5 butir, yaitu kesesuaian materi dengan perkembangan bahasa arab, contoh dan kasus akurat, gambar dan ilustrasi aktual, menggunakan contoh dan kasus Indonesia Arab, dan kemutakhiran pustaka. Dari segi kesesuaian materi dengan perkembangan bahasa Arab, mataeri-materi yang disajikan sudah sesuai dengan perkembangan bahasa Arab. Dari segi contoh dan kasus akurat Dari segi gambar

${ }^{8}$ Anggota BSNP,Artikel Tentang Kinerja BSNP Tahun 2014 (Jakarta: Badan Standar Nasional Pendidikan, 2014). Hal. 7. 
dan ilustrasi aktual, terdapat beberapa gambar dan ilustrasi yang tidak aktual sehingga tidak efektif jika disajikan kepada peserta didik. Dari segi menggunakan contoh dan kasus Indonesia Arab, Contoh dan kasus yang disajikan sesuai dengan budaya Indonesia dan budaya Arab yang benar. Dan dari segi kemutakhiran pustaka, beberapa pustaka yang digunakan diantaranya tidak mencerminkan pustaka yang relevan dan mutakhir, karena dalam penulisannya tidak dituliskan tahun terbitnya.

Subkomponen yang keempat, yaitu kesesuaian budaya, yang terdiri dari 2 butir, yaitu cakupan tema dan wawasan kebangsaan. Dari segi cakupan tema, Tema mencakupi tema-tema yang terkait budaya Arab dan Indonesia, hanya saja budaya Indonesia lebih banyak dari budaya Arabnya. Sedangkan dari segi wawasan kebangsaan, materi dapat membuka wawasan peserta didik untuk menghargai perbedaan budaya, adat istiadat, agama, serta menghindari persoalan SARA, HAM, dan bias gender. Unsur-unsur budaya sudah sesuai dengan unsur budaya Arab (Islami) dan budaya Indonesia yang meningkatkan rasa kebangsaan peserta didik.

Subkomponen yang kelima, yaitu latihan dan evaluasi, yang terdir dari 2 butir, yaitu latihan penguatan dan evaluasi kemampuan. Dari segi latihan penguatan, latihan-latihan yang disajikan sudah sesuai yaitu berupa struktur gramatika, pola (pattern practice), dan latihan komunikatif (communicative drill) untuk menguasai dan menerapkan materi-materi yang diajarkan, hanya saja untuk latihan komunikatif kurang sesuai, baik dari segi jenisnya (monolog ataupun dialog), dari segi penyajiannya yang tidak disajikan dengan gambar yang sesuai dan menarik peserta didik.

Subkomponen keenam, yaitu pengayaan yang terdiri dari 3 butir, yaitu materi pengayaan kosakata (mufroda:t), materi pengayaan gramatika (qawa:id), dan materi pengayaan keterampilan. Dari segi materi pengayaan kosakata (mufroda:t), Materi pengayaan sudah berisi pengembangan kosakata yang dituntut oleh kompetensi inti (KI) dan kompetensi dasar (KD), yang berorientasi pada kosakata nomina (isim), dan verba (fi'il). Dari segi materi pengayaan gramatika (qawa:id), materi pengayaan sudah berisi pengembangan gramatika sesuai dengan tingkat dan jenjang peserta didik, baik morfologi (sharaf), mapun sintaksis (nahwu). Dan dari segi materi pengayaan keterampilan, materi pengayaan sudah berisi pengembangan 4 (empat) keterampilan berbahasa, hanya saja untuk keterampilan berbiacara lebih sedikit dari keterampilan yang lainnya.

El-Ibtikar Vol 7 No 2 Nopember 2018, 115-136 


\section{Pola Penyajian Bahan Ajar Berdasarkan dengan Teori Mackey}

Menurut William Francis Mackey, mengungkap aspek bahwa bahan ajar yang baik itu dengan melihat pada empat kriteria, yaitu : 1) seleksi; 2) gradasi; 3) presentasi; dan 4) repetisi. ${ }^{9}$

1. Seleksi

Tidak ada satu metode yang ada di dunia ini yang dapat mengajarkan semua aspek yang ada dalam bahasa. Disengaja atau tidak, dilakukan dengan baik atau tidak, suatu metode mengajar bahasa mengadakan seleksi terhadap materi-materi yang akan diajarkan, baik seleksi terhadap tata bunyi, kosakata, semantika, maupun gramatika. Karena jumlahnya yang banyak dan ruang lingkupnya yang luas, maka bidang kosakatalah yang mudah untuk diseleksi dan memang seharusnya mengalami seleksi, karena dari rartusan ribu kata yang ada hanya beberapa ribu saja yang diajarkan dan diketahui. Hal-hal yang diperhatikan untuk menyeleksi kosakata yaitu tujuan belajar bahasa, tingkat kemahiran, dan lama waktu belajar.

\section{Gradasi}

Mackey mengemukakan dua aspek yang harus ada dalam gradasi, yaitu pengelompokkan (grouping) dan pengurutan (gradatiion). Pengelompokkan harus didasarkan pada prinsip-prinsip keseragaman, kekontrasan, dan keparalelan. Sedangkan pengurutan harus didasarkan pada prinsip psikologi belajar yaitu dari umum ke khusus, dari yang ringkas ke yang panjang, dari yang sederhana ke yang kompleks.

3. Presentasi

Setelah melewati tahap seleksi dan gradasi selanjutnya tahap presentasi. Presentasi yaitu bagaimana materi yang telah diseleksi dan dikelompokkan dapat disampaikan dan difahami oleh murid. Berikut terdapat beberapa prosedur dalam menyajikan sebuah materi :

a. Prosedur diferensial

Prosedur diferensial adalah prosedur yang didasarkan atas perbedaan arti antara bahasa kesatu dan bahasa kedua. Menurut prosedur ini untuk memahami suatu arti digunakan bahasa murid, yaitu dengan penjelasan bahasa murid atau dengan menterjemahkan kedalam bahasa murid.

${ }^{9}$ Muljanto Sumardi, Pengajaran Bahasa Asing: Sebuah Tinjauan dari Segi Metodologi (Jakarta: Bulan Bintang, 1974). Hal. 42-56.

El-Ibtikar Vol 7 No 2 Nopember 2018, 115-136 
Bahasa murid dapat digunakan untuk menjelaskan arti suatu kata dan penggunanannya, kaidah tata bahasa, perbedaan pola kalimat, bunyi, dan lain-lain. Kesulitan dalam cara ini adalah banyak istilah dan kata asing yang belum ada terjemahannya dalam bahasa murid.

b. Prosedur otensif

Prosedur otensif adalah prosedur mengajar bahasa dengan menggunakan gerak-gerik tangan dan muka dan lain-lain. Untuk mengajarkan kata benda dapat dilakukan dengan menunjuk bendabenda tersebut. Kata kerja dapat diajarkan dengan menunjukkan gerak gerik tangan atau anggota badan lainnya.

c. Prosedur piktoral

Prosedur piktoral adalah prosedur mengajar dengan menggunakan gambar. Ada tiga macam gambar yang digunakan dalam mengajar bahasa yaitu sebagai berikut :

a) Gambar tematik

Gambar tematik adalah gambar yang digunakan sebagai ilustrasi suatu tema atau teks. Misalnya gambar suatu keluarga yang sedang makan bersama, atau gambar pemandangan alam.

b) Gambar mnemonic

Gambar mnemonic adalah gambar yang dibuat untuk membantu murid mengingat arti kata atau kalimat tertentu. Gambar mnemonic dapat berupa gambar situasi yang secara simultan disajikan degan kalimat-kalimat mengenai situasi terebut.

c) Gambar semantik

Gambar semantik adalah gambar untuk mengajarkan arti. Oleh karena itu, gambarnya harus jelas dan tidak bermakna ganda. Disamping gambar-gambar tersebut. Media lainnya yang dapat digunakan ialah film, film strips, slides, gambar dinding, flash cards, dan stick figures.

d. Prosedur konteks

Prosedur konteks adalah prosedur mengajar yang sifatnya verbal. Seperti penggunaan definisi, enumerasi, substitusi, metaphor, oposisi, dan konteks ganda.

4. Repetisi

Mackey membagi kelompok repetisi menjadi empat bagian yang disesuaikan dengan keempat keterampilan berbahasa, yaitu menyimak, berbicara, membaca, dan menulis. 
Dalam bahan ajar ini didesain dengan keempat keterampilan berbahasa ditambah lagi dengan kaidah bahasa Arab dan latihan-latihan untuk mengevaluasi kemampuan siswa. Tetapi tidak ditemukan repetisi untuk kosakata.

\section{Analisis Bahan Ajar Berdasarkan Teori Mackey}

Berikut telaah bahan ajar "buku siswa bahasa Arab" untuk kelas 6 MI pendekatan saintifik 2013 terbitan kemenag RI berdasarkan teori Mackey :

\section{Seleksi}

Mackey mengajukan beberapa prinsip yang melandasi seleksi, yaitu tujuan belajar, tingkat kemampuan siswa, dan lama waktu belajar.

Pertama adalah tujuan belajar, dalam buku ini dipaparkan tentang $\mathrm{KI}$ dan $\mathrm{KD}$, indicator dan tujuan pembelajaran yang ingin dicapai guru.

Diambil contoh, dalam bab 6 أعمالنا في المدرسة و البيت beberapa Kompetensi Inti (KI) dan Kompetensi dasar (KD) yang ingin dicapai meliputi :

Semester Ganjil (1)

\begin{tabular}{|c|c|}
\hline KOMPETENSI INTI (KI) & KOMPETENSI DASAR (KD) \\
\hline $\begin{array}{l}\text { 5. Menerima, menjalankan dan } \\
\text { menghargai ajaran agama } \\
\text { Islam }\end{array}$ & $\begin{array}{l}\text { 5.1 Meresapi makna anugerah } \\
\text { Allah SWT. berupa bahasa } \\
\text { Arab } \\
\text { 5.2 } \\
\text { Meresapi makna anugerah } \\
\text { Allah SWT. atas terciptanya } \\
\text { bahasa yang beragam }\end{array}$ \\
\hline $\begin{array}{l}\text { 6. Menunjukkan perilaku } \\
\text { jujur, disiplin, tanggung } \\
\text { jawab, santun, peduli, dan } \\
\text { percaya diri, dalam } \\
\text { berinteraksi dengan } \\
\text { keluarga, teman, guru, dan } \\
\text { tetangganya serta cinta } \\
\text { tanah air }\end{array}$ & 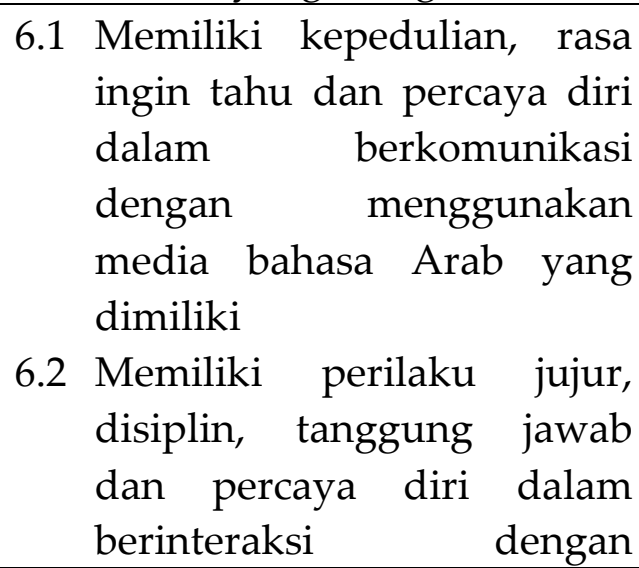 \\
\hline
\end{tabular}

El-Ibtikar Vol 7 No 2 Nopember 2018, 115-136 


\begin{tabular}{|c|c|}
\hline & $\begin{array}{l}\text { keluarga, teman, tetangga } \\
\text { dan guru dengan } \\
\text { menggunakan media bahasa } \\
\text { Arab yang dikuasai }\end{array}$ \\
\hline $\begin{array}{l}\text { 7. Memahami pengetahuan } \\
\text { factual dan konseptual } \\
\text { dengan menanya dan } \\
\text { mencoba berdasarkan rasa } \\
\text { ingin tahu tentang dirinya, } \\
\text { makhluk ciptaan Tuhan dan } \\
\text { kegiatannya, dan benda- } \\
\text { benda yang dijumpainya } \\
\text { dirumah, sekolah, dan } \\
\text { tempat bermain. }\end{array}$ & 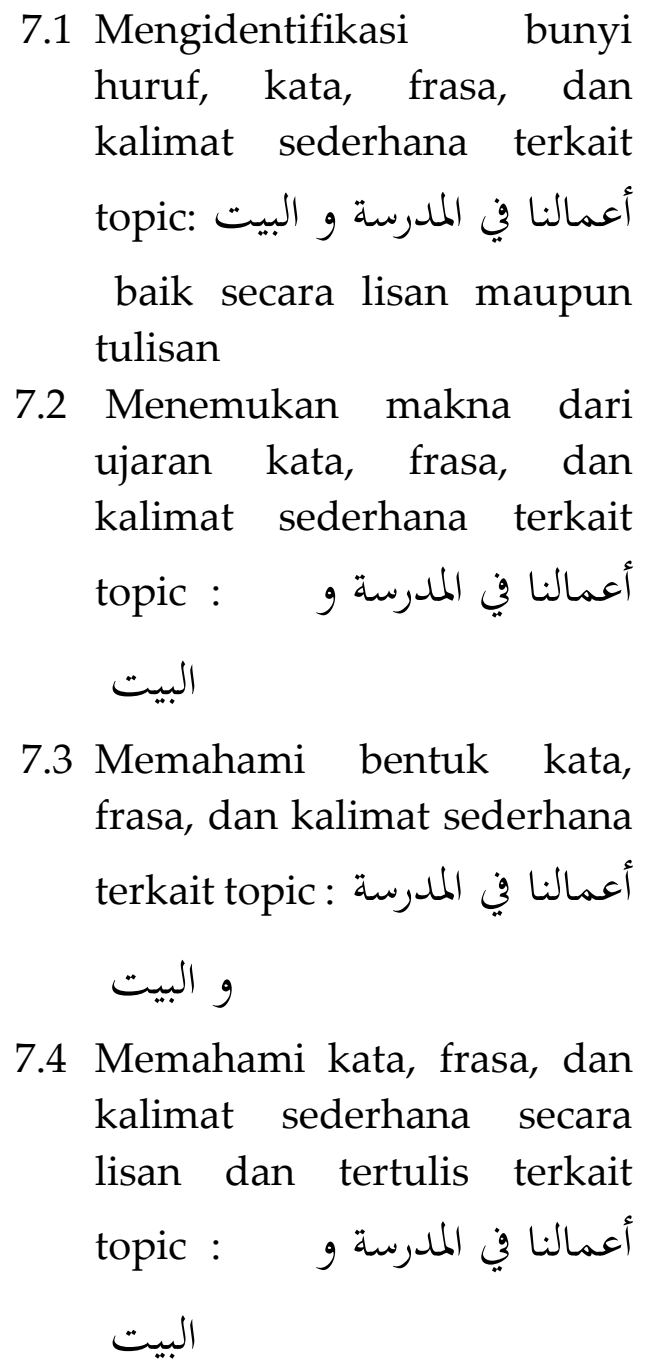 \\
\hline $\begin{array}{l}\text { 8. Menyajikan pengetahuan } \\
\text { factual dan konseptual } \\
\text { dalam bahasa yang jelas, } \\
\text { sistematis, logis, dan kritis, } \\
\text { dalam karya yang estetis, } \\
\text { dalam gerakan yang } \\
\text { mencerminkan anak sehat, } \\
\text { dan dalam tindakan yang }\end{array}$ & $\begin{array}{l}\text { 8.1 Melafalkan bunyi huruf, } \\
\text { kata, frasa, dan kalimat } \\
\text { bahasa Arab terkait topic : } \\
\text { أعمالنا في المدرسة و البيت } \\
\text { 8.2 } \\
\text { Menyampaikan makna dari } \\
\text { ujaran kata, frasa, dan } \\
\text { kalimat-kalimat sederhana }\end{array}$ \\
\hline
\end{tabular}




\begin{tabular}{|c|c|}
\hline $\begin{array}{l}\text { mencerminkan perilaku } \\
\text { anak beriman dan berkahlak } \\
\text { mulia. }\end{array}$ & 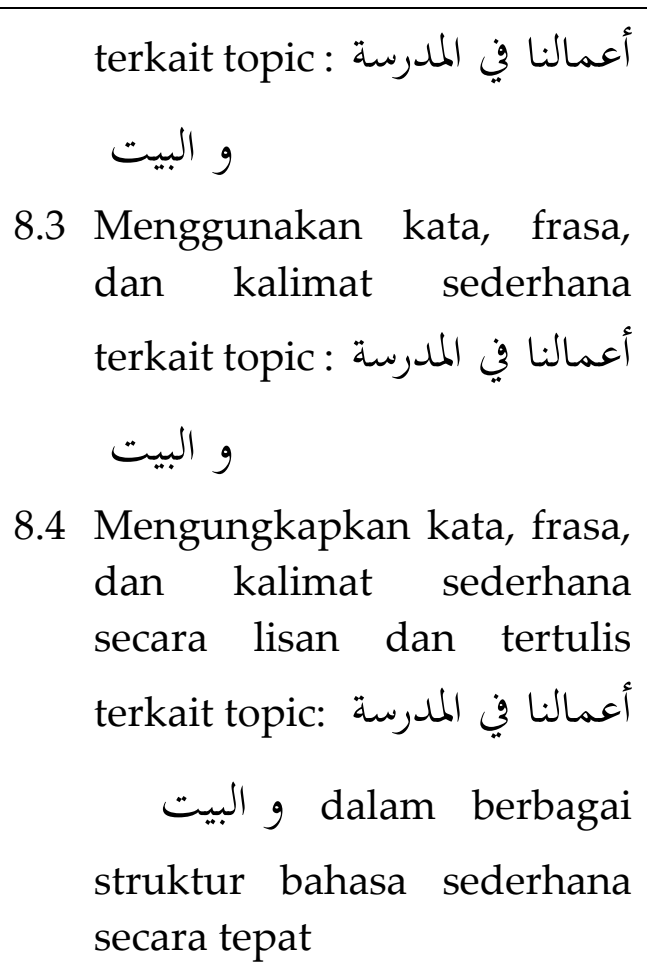 \\
\hline Tarkib: & فعل المضارِ \\
\hline
\end{tabular}

Adapun tujuan pembelajaran dari tema ini adalah, setelah mengamati, menanya, mengeksplorasi, mengasosiasi, dan mengkomunikasikan peserta didik mampu mendengar, bercakap, membaca, dan menulis dengan bahasa Arab yang berkaitan dengan tema kegiatan kita di sekolah dan di rumah.

Waktu belajar yang dibutuhkan dalam menyelesaikan satu tema ini adalah dua bulan, dengan 2 jam pertemuan setiap minggunya. Dalam waktu yang ditentukan, diharapkan siswa dapat menguasai materi yang telah disajikan.

Sedangkan dilihat dari aspek psikologi siswa, bahan ajar ini masih bersifat umum juga cenderug sulit dari segi gramatikanya (qawa:id). Hal ini juga dikarenakan bahan ajar "buku siswa bahasa Arab" untuk kelas 6 MI pendekatan saintifik 2013 terbitan kemenag baru beberapa bulan. Alangkah lebih baiknya guru membuat bahan ajar yang disesuaikan dengan psikologi siswa dan tingkat kemampuannya.

2. Gradasi

Mackey mengemukakan dua aspek yang harus ada dalam gradasi, yaitu pengelompokkan (grouping) dan pengurutan (gradatiion). 
Pengelompokkan harus didasarkan pada prinsip-prinsip keseragaman, kekontrasan, dan keparalelan. Sedangkan pengurutan harus didasarkan pada prinsip psikologi belajar yaitu dari umum ke khusus, dari yang ringkas ke yang panjang, dari yang sederhana ke yang komplek.

Dalam pengelompokkan, penyusun mendesain kosakata, ungkapan, mendengar, berbicara, membaca, dan menulis dalam sattu tema. penyusun juga menambahkan kaidah-kaidah bahasa Arab yang sudah dipilih untuk menyesuaikan kemampuan siswa beserta latihanlatihan di setiap keterampilan.

Dalam hal kemampuan psikologi siswa, penyusun telah memilih kaidah-kaidah dasar yang sesuai dengan tingkat kesulitan yaitu dari yang mudah ke yang sulit. Dalam hal ini, dilihat dari kaidah nahwu yang didesain penyusun dimulai dari pengenalan fi'il mudhari, as-sa'ah, fi'il 'amr, fi'il madhi, dan istifhaam. Kaidah-kaidah terebut disampaikan dengan berbagai contoh yang ringan disertai dengan terjemahannya. Hal ini memudahkan siswa untuk memahami isi buku.

3. Presentasi

Setelah melewati tahap seleksi dan gradasi selanjutnya tahap presentasi. Presentasi yaitu bagaimana materi yang telah diseleksi dan dikelompokkan dapat disampaikan dan difahami oleh murid. Berikut terdapat beberapa prosedur dalam menyajikan sebuah materi :

a. Prosedur diferensial

Prosedur diferensial adalah prosedur yang didasarkan atas perbedaan arti antara bahasa kesatu dan bahasa kedua. Hal ini dapat dilihat pada mufradat, 'ibarah, dan tarkib dimana terdapat bahasa Arab sebagai bahasa asing dan terdapat bahasa Indonesia sebagai bahasa ibu atau pengertian dari bahasa Arab tersebut.

b. Prosedur otensif

Prosedur otensif adalah prosedur mengajar bahasa dengan menggunakan gerak-gerik tangan dan muka dan lain-lain. Untuk mengajarkan kata benda dapat dilakukan dengan menunjuk bendabenda tersebut. Kata kerja dapat diajarkan dengan menunjukkan gerak gerik tangan atau anggota badan lainnya, seperti memeragakan kegiatan menyapu, atau menulis, dan lainnya.

c. Prosedur piktoral 
Prosedur piktoral adalah prosedur mengajar dengan menggunakan gambar. Ada tiga macam gambar yang digunakan dalam mengajar bahasa yaitu sebagai berikut :

1) Gambar Tematik

Gambar tematik adalah gambar yang digunakan sebagai ilustrasi suatu tema atau teks. Misalnya gambar kegiatan-kegiatan yang ada di sekolah maupun dirumah seperti pada Bab 1, atau gambar berbagai jam seperti di Bab 2 .

2) Gambar Mnemonik

Gambar mnemonic adalah gambar yang dibuat untuk membantu murid mengingat arti kata atau kalimat tertentu. Gambar mnemonic dapat berupa gambar situasi yang secara simultan disajikan dengan kalimat-kalimat mengenai situasi tersebut, seperti gambar siswa yang sedang belajar (membaca atau menulis buku), atau gambar seorang anak yang sedang berwudhu.

3) Gambar Semantik

Gambar semantic adalah gambar untuk mengajarkan arti. Oleh karena itu, gambarnya harus jelas dan tidak bermakna ganda. Disamping gambar-gambar tersebut, media lainnya yang dapat digunakan adalah film, film strips, slides, gambar dinding, flash cards, dan stick figures.

d. Prosedur konteks

Prosedur konteks adalah prosedur mengajar yang sifatnya verbal. Seperti penggunaan definisi, enumerasi, substitusi, metaphor, oposisi, dan konteks ganda.

Keempat prosedur diatas, kebanyakan sudah diterapkan dalam mendesain bahan ajar ini. Dapat dilihat dari kosakata bahasa Arab disertai dengan gambar-gambar, penjelasan kaidah dalam bahasa Indonesia dan disertai contoh-contoh didalamnya, dan gambar-gambar yang sesuai dengan ungkapan pada topik ini akan memudahkan siswa dalam memahami teks atau bacaan.

\section{Repetisi}

Mackey membagi kelompok repetisi menjadi empat bagian yang disesuaikan dengan keempat keterampilan berbahasa, yaitu menyimak, berbicara, membaca, dan menulis.

Dalam bahan ajar ini didesain dengan keempat keterampilan berbahasa ditambah lagi dengan kaidah bahasa Arab dan latihan-latihan El-Ibtikar Vol 7 No 2 Nopember 2018, 115-136 
untuk mengevaluasi kemampuan siswa. Tetapi tidak ditemukan repetisi untuk kosakata. Berikut rangkuman repetisi dalam topik "kegiatan kita di sekolah dan rumah" dibawah ini:

$$
\begin{aligned}
& \text { أ. اختر الحروف أ، ب، ج، او د للاجوبة الصّحيحة ! }
\end{aligned}
$$

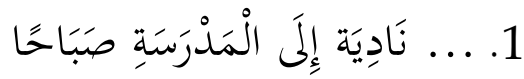

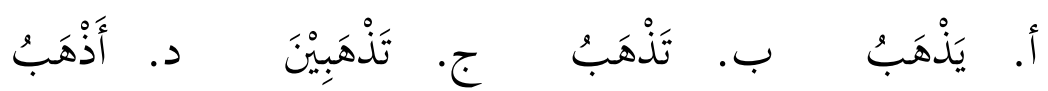

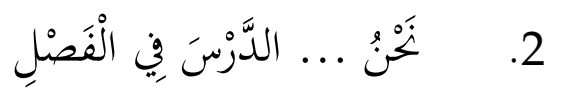

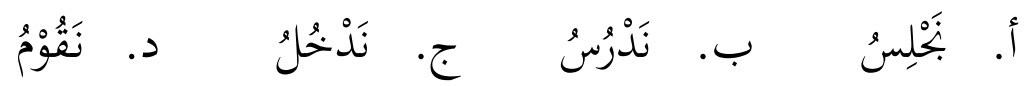

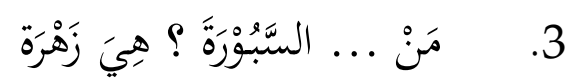

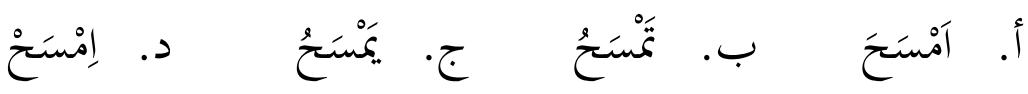

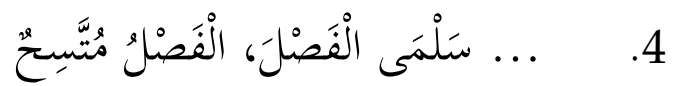

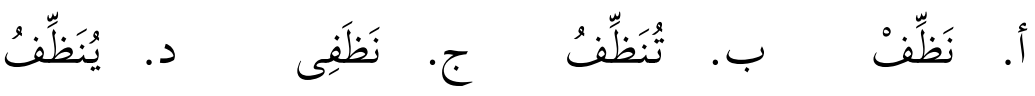

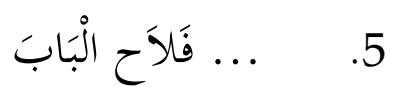

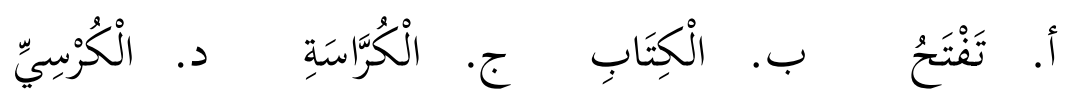

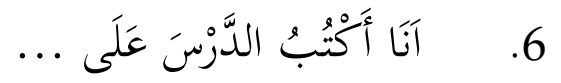

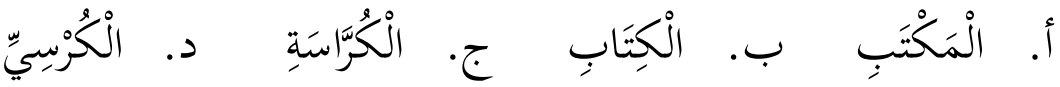

$$
\text { ... . }
$$

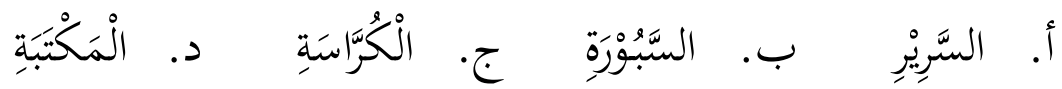

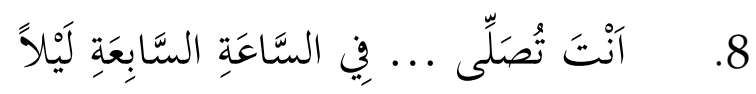

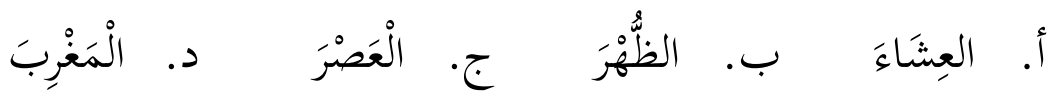

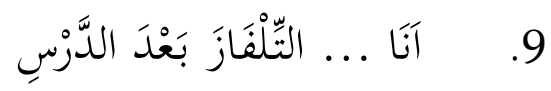

$$
\text { 10. أَ أَقْوُُْ }
$$




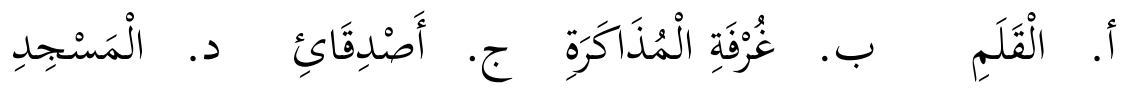

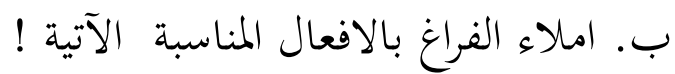

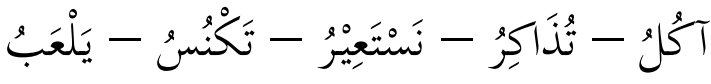

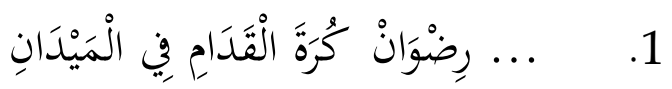

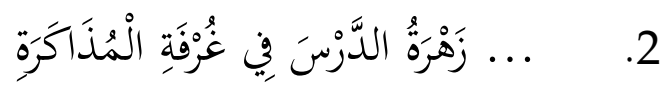

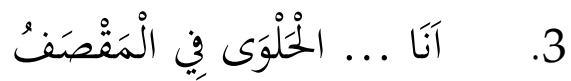

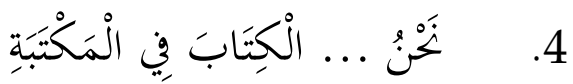

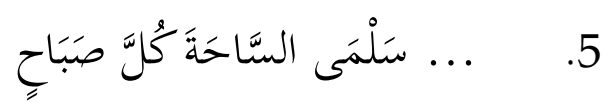

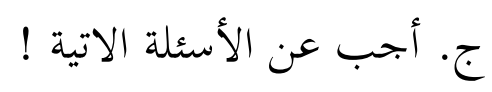

(Jawablah pertanyaan-pertanyaan berikut!)

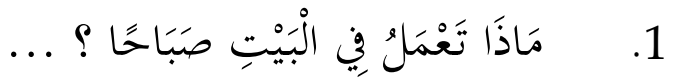

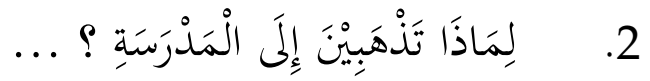

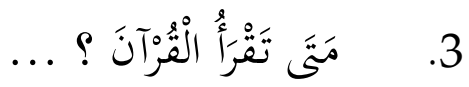

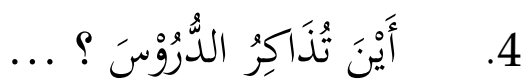

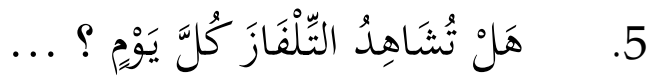

د. ترجم الجمل الاتيات باللغة الاندونيسيّة !

(Terjemahkanlah kalimat-kalimat berikut dalam bahasa Indonesia !)

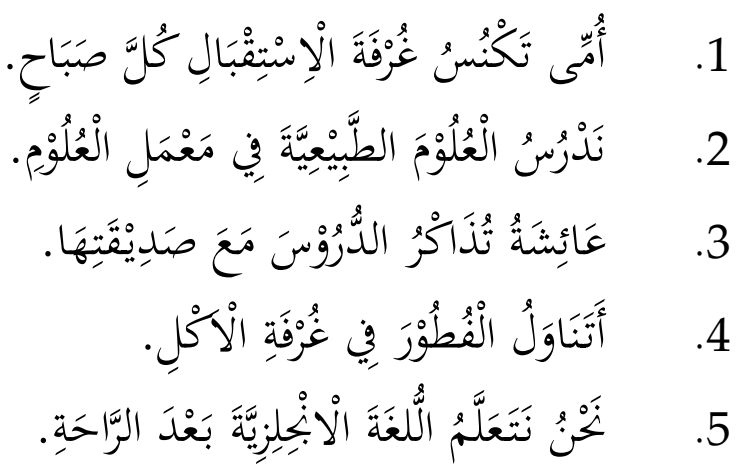




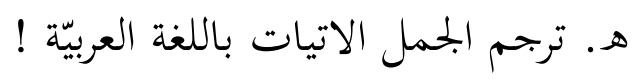

(Terjemahkanlah kalimat-kalimat berikut dalam bahasa Arab!)

1. Anisa meminjam buku di perpustakaan

2. Royyan bermian bola basket di halaman

3. Firda meletakkan buah anggur di kulkas

4. Ayahku pulang dari kantor sore hari

5. Kami makan malam bersama setelah maghrib

\section{Kesimpulan}

Setelah analisis bahan ajar "buku siswa bahasa Arab" untuk kelas 6 Madsrasah Ibtidaiyah terbitan Kementerian Agama Republik Indonesia, dapat disimpulkan bahwa sudah sesuai dengan kompetensi Inti (KI) dan kompetensi dasar (KD) yang terdiri dari 6 subkomponen yaitu kesesuaian uraian materi dengan KI dan KD, keakuratan materi, kemutakhiran materi, kesesuaian budaya, latihan dan evaluasi, dan pengayaan. Juga sesuai dengan teori Mackey yang meliputi seleksi, gradasi, presentasi, dan repetisi.

\section{Daftar Pustaka}

Anggota BSNP. 2014. Artikel Tentang Kinerja BSNP Tahun 2014. Jakarta: Badan Standar Nasional Pendidikan.

Azizah, Mutiatul. "Pdf Skripsi Analisis Bahan Ajar." 2016. digilib. uinsby.ac.id (diakses Februari 23, 2016).

Lampiran SK. DIRJEN. Pendidikan Islam. Kurikulum 2013 Mata Pelajaran Pendidikan Agama Islam dan Bahasa Arab di Madrasah. Nomor 2676 Tahun 2013.

Muljanto, Sumardi. 1974. Pengajaan Bahasa Asing : Sebuah tinjauan dari segi Metodologi. Jakarta: Bulan Bintang.

Nirmala Ratna, Nur Fitria. 2015. Persepsi Guru Kelas II (Dua) terhadap Pelaksanaan Proses Penialian dalam Kurikulum 2013 di SD Al-Firdaus Surakarta Tahun Ajaran 2013/2014. Surakarta: Universitas Muhammdiyah Surakarta.

Taruna, Mulyani Muds. "Kesiapan Madrasah Dalam Pelaksanaan Kurikulum 2013." Juranal At-Taqaddum 6, no. 2 (Nopember 2014): 215. 